\title{
AKUMULASI LOGAM BERAT KROM(Cr) PADA TANAMAN KENTANG (Solanum tuberosum L.)AKIBAT PEMBERIAN PESTISIDA, PUPUK ORGANIK DAN KOMBINASINYA
}

\author{
M. Manurung ${ }^{1,2^{*}}$, Y. Setyo ${ }^{3}$, dan N. P. N. Repli Suandewi ${ }^{2 *}$ \\ ${ }^{\text {l}}$ Progam Studi Kimia Fakultas Matematika dan Ilmu Pengetahuan Alam Universitas Udayana \\ ${ }^{2}$ Program Studi Magister Kimia Terapan,FMIPA Universitas Udayana, Denpasar, Bali \\ ${ }^{3}$ Fakultas Teknologi Pertanian Universitas Udayana, Kampus Bukit Jimbaran, Bali \\ *Email: manuntun_manurung@unud.ac.id \\ *Email: faski@unud.ac.id
}

\begin{abstract}
ABSTRAK
Pada saat ini para petani kentang cenderung berorientasi pada produksi yang tinggi, tanpa memperhatikan kualitas kentang yang dihasilkan, khususnya kandungan logam berat krom. Penelitian ini bertujuan untuk mengetahui pengaruh pemberian pupuk organik, pestisida dan kombinasinya terhadap peningkatan kadar logam berat krom (Cr), serta distribusinya pada tanaman kentang( Solanum tuberosum L.). Penelitian dilakukan dengan empat perlakuan yang berbeda yaitu; tanaman kentang tanpa perlakuan $\left(\mathrm{P}_{1}\right)$, diberi pestisida( $\left.\mathrm{P}_{2}\right)$, diberi pupuk Organik $\left(\mathrm{P}_{3}\right)$, diberi pestisida dan pupuk organik $\left(\mathrm{P}_{4}\right)$. Pengamatan dilakukan mulai dari pembibitan hingga pada pasca panen. Akumulasi logam krom total pada setiap bagian tanaman dianalisis secara perodik, setiap bulan menggunakan spektofotometer serapan atom. Hasil penelitian menunjukkan bahwa lahan pertanian, pestisida, pupuk organik dan bibit kentang mengandung logam berat $\mathrm{Cr}$. Pemberian pestisida, pupuk organik dan kombinasinya berperan dalam meningkatkan kandungan logam berat krom pada setiap bagian tanaman kentang.
\end{abstract}

Kata kunci: kentang, kromium, logam berat, pestisida, pupuk oganik

\begin{abstract}
Currently potato farmers in Indonesia tend to orient a high production without concerning the heavy metals content such as chromium in the crops produced. This research aimed to determine the effect of the application of pesticides, organic fertilizer and its combinations on the accumulation of chromium content, as well as its distribution in potatoes crops (Solanum tuberosum L.). The study was conducted with four different treatments to the soils namely, without treatment, given pesticide, given organic fertilizer, and their combinations. The obsservations were carried out from seeding to post harvest. The accumulation of the total chromium on each part of the plant and soil was analized periodically every month using the atomic absorption spectrophotometer (AAS). The results showed that the agricultural soil, pesticides, organic fertilizers and the potato seeds have already contained chromium. It was evident that, the application of pesticides, organic fertilizers and their combination play a role in increasing the chromium content in the soils as well as in every part of the potato plant.
\end{abstract}

Keywords: Heavy metal, chromium, potatoes, pesticide, organic fertilizer

\section{PENDAHULUAN}

Sistem pertanian Indonesia dengan penggunaan pestisida dan pupuk kimia membawa dampak buruk bagi ekosistem pertanian. Dampak tersebut membawa para petani kembali ke pertanian organik. Pada kenyataanya, pertanian organik tidak serta merta terbebas dari pencemaran terutama logam berat. Berdasarkan hasil penelitian yang dilakukan oleh Kusdianti, et al. (2014) menunjukkan adanya peningkatan akumulasi logam kadimum (Cd) di umbi kentang dimulai dari 26 hari setelah tanam dan saat panen pada tanah yang tercemar logam berat $\mathrm{Cd}$. Pada awal tanam atau 26 HST (hari setelah tanam) kandungan kadmium dalam umbi kentang kurang dari 0,01 ppm. Pada saat panen, rata-rata kandungan kadmium dalam umbi kentang naik mencapai 0,078 ppm, artinya naik hampir $700 \%$. Kandungan logam berat dalam tanah akan 
berpengaruh terhadap terhadap kandungan logam pada tanaman yang tumbuh di atasnya ,sebab tanah merupakan bagian dari siklus logam berat (Hidayat, 2015).

Salah satu upaya mengurangi akumulasi logam berat dalam tanah adalah dengan pemupukan menggunakan kompos. Pemu pukan menggunakan kompos adalah salah satu praktek budidaya yang baik Good Agriculture Practices (GAP). Praktek ini juga sesuai dengan sistem low external input on sustainable agriculture (LEISA) yaitu meng amankan kondisi tanah yang sesuai untuk pertumbuhan tanaman (Yohanes, et al., 2017). Namun, pupuk organik tidak serta merta terbebas dari logam berat. Berdasarkan penelitian yang dilakukan oleh Khatimah (2006), terdapat cemaran logam berat dalam beberapa jenis pupuk organik, seperti pupuk kandang berkisar antara 1,8 - 410 ppm untuk logam Cr.

Desa Candikuning, Kecamatan Baturiti, Kabupaten Tabanan merupakan salah satu daerah pusat pembudidayaan tanaman kentang, di Bali. Dilihat dari aspek agronomis daerah tersebut memiliki kondisi tanah dan iklim yang cocok untuk tanaman kentang. Berdasarkan Setiyo, et al., (2013) dalam Yohanes (2017), petani kentang Desa Candikuning sangat intensif menggunakan fungisida jenis; Daconil, Akrobat, Antracol, dan Dithane M45, sedangkan kelompok insektisida yang digunakan petani adalah Curacron dan Detracon. Penggunaan pestisida secara terus menerus turut berperan menambah unsur logam atau mineral pada tanah, dan resistensi terhadap hama (Edwards, 2017).

Studi pendahuluan yang dilakukan sebelumnya oleh peneliti menunjukkan bahwa pestisida dan fungisida yang digunakan petani kentang, seperti disebutkan ternyata juga mengandung logam berat krom.(Cr)

Penelitian ini dilakukan untuk menge tahui pengaruh penggunaan pestisida, pupuk organik, dan kombinasinya terhadap akumulasi logam berat kromium $(\mathrm{Cr})$ serta distribusinya pada tanaman kentang( Solanum tuberosum L.).

\section{MATERI DAN METODE}

\section{Bahan}

Bahan - bahan yang digunakan pada penelitian ini adalah bibit tanaman kentang (Solanum tuberosum L.) varietas granola. Alasan pemilihan bibit ini adalah lebih cocok pada daerah tersebut karena memiliki ketinggian tempat $700 \mathrm{mdpl}$ dan unggul dibudidayakan pada daerah tersebut. Bahan penelitian selanjutnya adalah tanah lahan budidaya, pupuk organik campuran dari gabah padi, kotoran ayam, kotoran sapi, pupuk organik kemasan merk Dopos dan pestisida jenis Antracol, Acrobat, Dithane $\mathrm{M} 45 . \mathrm{HNO}_{3}$ Pekat, $\mathrm{HCl}$ pekat, aquades, larutan stok Cr 1000 ppm.

\section{Peralatan}

Alat yang digunakan meliputi plastik klip, sekop kecil, cawan petri, mortar, hot plate, timbangan analitik, peralatan gelas seperti, pipet volumetrik, cawan petri, pengaduk magnetik, timbangan analitik, oven, dan instrumen SSA Shimadzu/AA-7000 series. Ayakan ukuran 60 mesh.

\section{CARA KERJA}

Preparasi Sampel.

Preparasi sampel tanaman kentang (Solanum tuberosum L.), tanah, pupuk organik dan pestisida diadaptasi dari Environmental Protection Agency Protocol, Kuwata, 2010.

Sampel kentang dicuci dengan air bersih kemudian dipotong-potong menjadi ukuran yang lebih kecil dan dikeringkan dalam oven pada suhu $130^{\circ} \mathrm{C}$ hingga kering dan berat konstan. Sampel yang sudah kering didinginkan kemudian dihaluskan lalu diayak dengan ayakan 60 mesh.

\section{Analisis sampel}

Bubuk kentang ditimbang sebanyak $5 \mathrm{~g}$ dimasukkan ke dalam gelas kimia $100 \mathrm{~mL}$, lalu ditambahkan. $5 \mathrm{~mL}$ aquades dan $5 \mathrm{~mL}$ asam nitrat $\left(\mathrm{HNO}_{3}\right)$ pekat. selanjutnya dilakukan pemanasan selama 5 menit pada suhu $100^{\circ} \mathrm{C}$. Larutan didinginkan, lalu ditambahkan kembali, $5 \mathrm{~mL} \mathrm{HNO}_{3}$ pekat dan dipanaskan pada suhu yang sama.Selanjutnya penambahan $\mathrm{HCl}$ pekat sebanyak $5 \mathrm{~mL}$ dilakukan secara perlahan - 
lahan yang diikuti dengan penambahan $10 \mathrm{~mL}$ aquades kemudian dipanaskan pada suhu $100^{\circ} \mathrm{C}$. Lakukan penyaringan larutan dengan kertas saring ke dalam labu ukur $50 \mathrm{~mL}$, ditambah $\mathrm{HNO}_{3} \quad 1 \%$ sampai tanda batas. Konsentrasi logam berat $\mathrm{Cr}$ diukur dengan menggunakan SSA, pada panjang gelombang maksimum $\tau_{\text {maks }}=357,72 \mathrm{~nm}$. Preparasi yang sama dilakukan pada sampel tanah, pupuk organik kecuali pestisida tidak melalui proses pengeringan.

\section{a. Analisis Awal/Pendahuluan}

Analisis pendahuluan kandungan logam total $\operatorname{krom}(\mathrm{Cr})$ pada semua sampel, seperti tanah, pestisida, pupuk organik dan bibit kentang.

\section{b. Analisis Perlakuan}

Analisis kandungan logam total krom (Cr) pada setiap Perlakuan P1, P2, P3 dan P4 di bulan ke-1, bulan ke-2 dan bulan ke-3 (pasca panen). Analisis distribusi logam tersebut pada bagian tanaman kentang meliputi akar, batang, daun dan umbi termasuk tanah budidaya. $\mathrm{P}=$ perlakuan, terhadap tanaman kentang. $\mathrm{P} 1=$ tanpa perlakuan, $\mathrm{P} 2=$ diberi pestisida, $\mathrm{P} 3=$ diberi pupuk organik, $\mathrm{P} 4$ = diberi pestisida dan pupuk organik (kombinasi).

\section{Pembuatan Kurva Kalibrasi}

Kurva kalibrasi dibuat dengan memipet larutan induk krom 1000 ppm, sebanyak 0; 1,5; 3; 6; dan $8 \mathrm{~mL}$, dimasukkan ke dalam lubu ukur $50 \mathrm{~mL}$, diencerkan dengan larutan $\mathrm{HNO}_{3} 1 \%$ hingga tanda batas. Hasilnya berupa deretan larutan stándar dengan konsentrasi 0, 3, 6, 12, dan 16 ppm. Absorbans larutan diukur dengan SSA pada panjang gelombang maksimum. Selanjutnya dibuat plot antara absorbans terhadap konsentrasi dan diperoleh persamaan Regresi linier $\mathrm{Y}=0,0116 \mathrm{x}+0,0021 ; \mathrm{y}=$ absorbans dan $\mathrm{x}=$ konsentrasi, $0,0021=$ titik potong terhadap sumbu-y. Koefisien regresi $\mathrm{r}^{2}=$ 0,9998. Persamaan digunakan untuk menentu kan konsentrasi logam dalam sampel.

\section{Analisis Pendahuluan Kandungan Logam Berat $\mathrm{Cr}$}

Hasil analisis kandungan logam krom awal pada sumber-sumber pencemar seperti Tabel 1.

Tabel 1 Kandungan Logam Berat Cr, awal pada sumber pencemar

\begin{tabular}{lc}
\hline \multicolumn{1}{c}{ Sampel } & Cr \\
\cline { 2 - 2 } & $\mathrm{mg} / \mathrm{kg}$ \\
\hline Tanah budidaya & 3,485 \\
Bibit kentang & 1,252 \\
Pupuk Organik & \\
- Gabah padi+kotoran ayam dan sapi & 4,729 \\
- Pupuk organik kemasan merk Dopos & 3,831 \\
Pestisida & \\
- Acrobat & 4,936 \\
- Dithane M45 & 4,522 \\
- Antracol & 4,729 \\
\hline
\end{tabular}

Hasil Tabel 1 menunjukkan bahwa tanah budi daya, bibit kentang, pupuk organik dan pestisida yang digunakan oleh petani mengandung logam berat krom $(\mathrm{Cr})$. Bibit kentang yang digunakan oleh petani berasal dari Desa Luwus, Kabupaten Tabanan. Konsentrsi logam berat $\mathrm{Cr}$ pada bibit kentang sebesar $0,1252 \mathrm{ppm}$, atau kadarnya $1,252 \mathrm{mg} / \mathrm{Kg}$, menunjukkan bahwa bibit kentang yang digunakan dalam pembudi dayaan ini sejak awal sudah mengandung logam krom $(\mathrm{Cr})$. Penggunaan pupuk organik yang dianggap sebagai salah satu cara untuk mengurangi logam berat $\mathrm{Cr}$ ternyata justru sebaliknya menjadi salah satu sumber pencemar. Kedua jenis pupuk organik yang digunakan memiliki kandungan logam $\mathrm{Cr}$ yang tidak jauh berbeda yakni sebesar 4,729 $\mathrm{mg} / \mathrm{kg}$ untuk jenis gabah padi, kotoran ayam dan sapi, dan sebanyak $3,831 \mathrm{mg} / \mathrm{kg}$ untuk pupuk organik kemasan merk Dopos yang tersebar luas di pasaran. Hal serupa juga ditemukan pada pestisida yang digunakan oleh petani. Para petani daerah tersebut intensif menggunakan lebih dari satu jenis pestisida (Tabel 1). 


\section{a.Analisis logam berat krom pada setiap perlakuan : P1, P2, P3, P4. dan distribusinya}

Hasil analisis kandungan logam krom pada tanah dan tanaman disetiap perlakuan $\mathrm{P} 1$, P2,P3 dan P4 untuk bulan ke-0, 1, 2, dan 3 disajikan pada Gambar1, 2, 3, 4, dan 5 berikut:

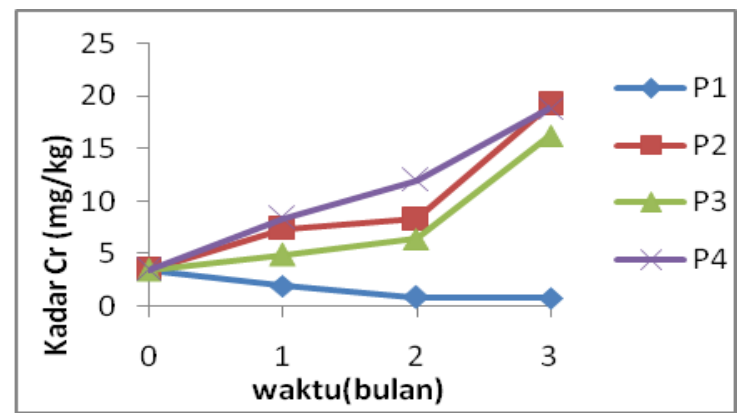

Gambar 1 Hubungan kandungan logam berat Cr terhadap waktu pada Tanah Budidaya tiap perlakuan

Kandungan logam $\mathrm{Cr}$ pada tanah budidaya diawal(P1) tanpa perlakuan pada bulan ke-0 sebesar 3,485 $\mathrm{mg} / \mathrm{Kg}$ dan semakin berkurang hingga pasca panen( bulan ke-3). Artinya tanaman kentang membutuhkan logam krom di dalam proses pertumbuhannya, yang sebagian diambil dari tanah.Namun dengan pemberian pestisida (P2) dan juga pemberian pupuk organik(P3), serta kobinasinya (P4), justru meningkatkan kandungan logam berat krom (Cr) pada tanah hingga mencapai kandungan tertinggi yaitu 19,150 mg/Kg.(Gambar 1, Tabel 4) Jadi pestisida dan pupuk orgainik yang digunakan petani di daerah Candikuning seperti Tabel 1, menyumbang peningkatan kandungan logam krom total pada tanah pertanian.

\section{b.Kandungan logam krom pada batang tanaman kentang.}

Pada keadaan awal tanaman kentang belum tumbuh, masih berupa bibit. Analisis dilakukan mulai bulan pertama, saat kentang berumur satu bulan.Hasilnya menunjukkan yang tanpa perlakuan( $\mathrm{P} 1)$ mengandung krom sebesar $4,020 \mathrm{mg} / \mathrm{Kg}$. Demikian juga dengan perlakuan P2,P3,P4 hingga pasca panen, ada kecende rungan peningkatan kadar krom dalam batang tanaman kentang di bandingkan dengan P1,di setiap bulan hingga pascapanen. Kandungan tertinggi pada perlakuan P4 yaitu sebesar 35,511 $\mathrm{mg} / \mathrm{Kg}$ (Gambar 2 dan Tabel 4).

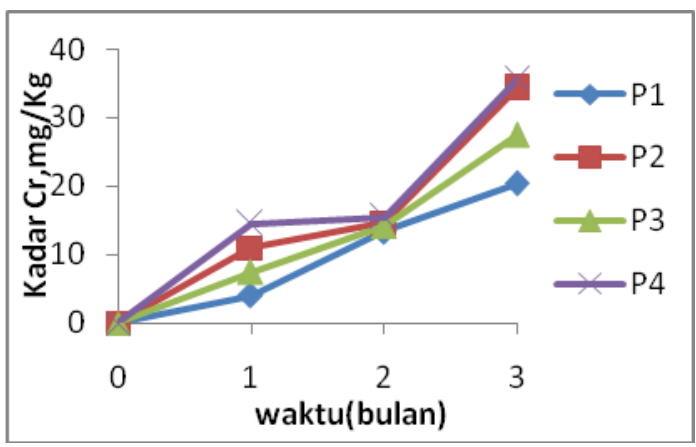

Gambar 2 Hubungan kandungan logam berat $\mathrm{Cr}$ terhadap waktu pada batang tanaman kentang tiap perlakuan

\section{c.Kandungan logam krom pada daun tanaman kentang.}

Hasil analisis kandungan logam krom pada daun tanaman kentang, untuk setiap perlakuan dan waktu disajikan seperti Gambar 3, berikut:

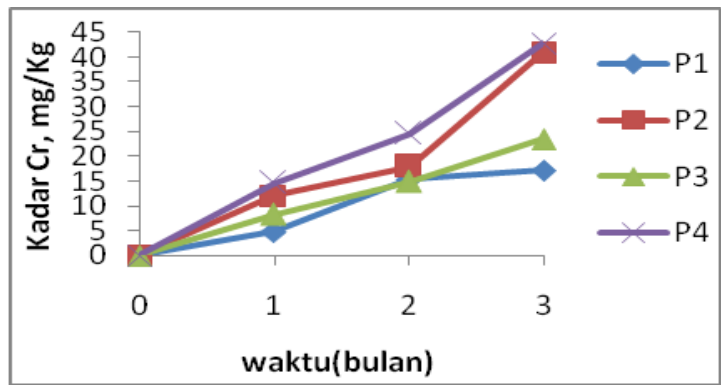

Gambar 3 Hubungan kandungan logam berat $\mathrm{Cr}$ terhadap waktu pada daun tanaman kentang tiap perlakuan

Sama seperti pada batang tanaman diawal tidak dilakukan analisis pada daun, sebab masih baru bertunas. Analisis dilakukan dibulan ke-1, ke-2 dan bulan ke-3. Kenyataan unik yang terjadi di lapangan dan berbuhungan dengan pening katan akumulasi $\mathrm{Cr}$ pada daun hingga mencapai 
42,791 mg/Kg,( Gambar 3,Tabel-4), merupakan yang tertinggi.Hal ini mungkin terjadi karena akumulasi logam berat $\mathrm{Cr}$ dari sumber pencemar lain seperti kebiasaan warga sekitar yang kerap membakar ban bekas untuk menghangatkan tubuh.. Mengingat daerah tersebut merupakan dataran tinggi yang sangat dingin. Bahan baku pembuatan ban salah satunya adalah kawat baja. Menurut Darmono, (1995) dalam Kartika et al., (2002), logam Cr digunakan sebagai pelapis baja sehingga baja bersifat kuat dan keras. Asap dari pembakaran ban secara tidak langsung akan mencemari udara dan terserap oleh stomata yang terdapat pada bagian daun. Daun merupakan salah satu bagian tanaman yang sangat rentan terhadap akumulasi, sebab daun memiliki stomata yang berfungsi sebagai penyerapan.

\section{d. Kandungan logam krom pada akar tanaman kentang.}

Hasil nalisis kandungan logam berat krom pada akar tanaman kentang untuk setiap perlakuan dan waktu disajikan seperti Gambar 4 berikut:

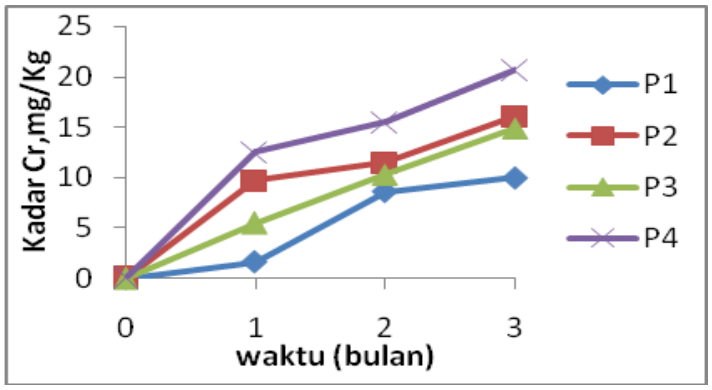

Gambar 4 Kandungan Logam Berat $\mathrm{Cr}$ terha dap waktu pada akar tanaman kentang tiap perlakuan

Tumbuhan umumnya menyerap unsur - unsur hara dan mineral yang larut dalam airmaupun dari tanah melalui akarnya. Tumbuhan memiliki kemampuan penyerapan yang memungkinkan pergerakan ion-ion menembus membran sel (Filter \& Hay, 1991 dalam Kartika et al., 2002). Hal ini berarti bahwa logam krom, secara kimiawi terikat lemah dengan unsur lain dalam pestisida, pupuk organik dan juga tanah, sehingga dengan mudah terlarut dan terdistribusi ke seluruh bagian tanaman.

e. Kandungan logam krom pada umbi tanaman kentang.

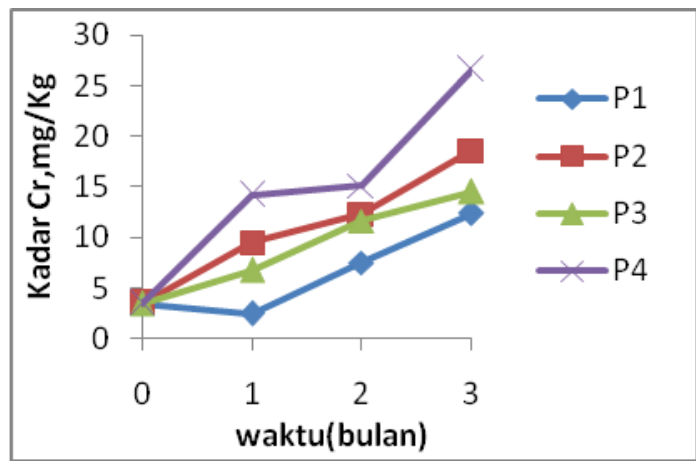

Gambar 5 Hubungan kandungan logam berat Cr terhadap waktu pada umbi tanaman kentang tiap perlakuan

Umbi kentang adalah bagian dari tanaman yang sangat berguna bagi para petani. Penggunaan pupuk organik dan pestisida di dalam pembudidayaan kentang memiliki satu tujuan yaitu menghasilkan umbi kentang yang sesuai dengan standar pasar nasional. Namun di sisi lain, bahaya yang ditimbulkan dari penggunaan kedua sumber pencemar ini adalah akumulasi logam yang melebihi SNI untuk bahan pangan. Berdasarkan Gambar 5 dan Tabel 4, akumulasi yang terjadi pada umbi kentang untuk logam $\mathrm{Cr}$ telah melebihi batas maksi mum SNI yang ditetapkan untuk bahan pangan yakni sebesar 0,01 mg/kg (SNI, 2009).

Pestisida yang digunakan di bidang pertanian dan holtikultura umumnya memiliki kandungan logam berat. Tujuan penggu naan pestisida adalah untuk mengendalikan hama dan penyakit tanaman. Pengunaan pestisida mengakibatkan tanah, air dan produk tanaman tercemar logam berat (Pramono dan Wahyuni, 2008). Penggunaan pestisida tidak dapat di pungkiri dapat meningkatkan kualitas hasil budidaya tetapi memiliki efek samping yang berbahaya bagi lingkungan sekitar seperti 
ternak, binatang dan manusia itu sendiri. Pupuk organik adalah pupuk yang berasal dari tanaman, kotoran hewan yang telah melalui proses rekayasa (Deptan, 2006). Penggunaan pupuk organik bertujuan untuk mengurangi pemanfaatan atau mensubstitusi pupuk kimia yang dianggap mence mari tanah. Perubahan sifat kimia tanah akibat pemupukan dengan kompos adalah pada meningkatnya ketersediaan unsur hara mikro dan makro yang dibutuhkan oleh tanaman (Sutanto, 2002 dalam Yohanes et al. 2017).

Fakta menunjukkan bahwa penggu naan pestisida dan pupuk organik berpenga ruh langsung terhadap produk umbi tanaman kentang seperti disajikan pada Tabel 2, berikut:

Tabel 2 Jumlah umbi/bulan/perlakuan

\begin{tabular}{lccc}
\hline Perlakuan & \multicolumn{3}{c}{ Jumlah umbi / bulan } \\
\cline { 2 - 4 } & \multicolumn{1}{c}{1} & 2 & 3 \\
\hline $\mathrm{P}_{1}$ & 1 buah & 4 buah & 4 buah \\
$\mathrm{P}_{2}$ & 1 buah & 5 buah & 5 buah \\
$\mathrm{P}_{3}$ & 1 buah & 6 buah & 6 buah \\
$\mathrm{P}_{4}$ & 2 buah & 6 buah & 8 buah
\end{tabular}

Kenyataan ini mendorong para petani lebih intensif menggunakan pestisida dan pupuk, tanpa berfikir kandungan kimia dari bahan yang digunakan. Berdasarkan Gambar 1, 2, 3, 4, dan 5. Tabel 4, menunjukkan bahwa pestisida dan pupuk organik, bersinergi menyumbang logam krom ke seluruh bagian tanaman. Penggunaan pestisida secara terus-menerus dapat menyebabkan resistensi hama dan juga perubahan sifat tanah (Edwards, 2017).

Hasil uji ANOVA terhadap kandungan logam krom tiap perlakuan pada kolom Sig. diperoleh nilai $\mathrm{P}=0.000(P$-value $)<0.05$ artinya terdapat perbedaan yang signifikan antar kelompok perlakuan akibat pemberian pestisida dan pupuk organik. Adanya perbedaan yang sangat nyata antar perlakuan maka dilanjutkan dengan uji Duncan. Hasil analisis statistik melalui Uji Duncan pada taraf signifikansi 0,05 menunjukkan berbeda nyata pada semua perlakuan. Data pada Tabel 3 (khusus umbi) memperlihatkan bahwa pemberian pestisida dan pupuk organik merupakan perlakuan yang paling tinggi kontribusinya terhadap akumulasi logam berat $\mathrm{Cr}$ pada umbi tanaman kentang.

Tabel 3 Uji Duncan pada Umbi Kentang di Masing - Masing Perlakuan Pasca Panen

\begin{tabular}{ccccc}
\hline $\begin{array}{c}\text { Logam } \\
\text { mg/Kg }\end{array}$ & P 1 & P 2 & P 3 & P4 \\
\hline $\mathrm{Cr}$ & $\begin{array}{c}12,424 \\
\text { (d) }\end{array}$ & $\begin{array}{c}18,628 \\
\text { (c) }\end{array}$ & $\begin{array}{c}14,54 \\
5(\mathrm{~b})\end{array}$ & $\begin{array}{c}26,663( \\
\text { a) }\end{array}$ \\
\hline
\end{tabular}

Ket: $\mathrm{P}=$ Perlakuan

= notasi $\mathrm{d}, \mathrm{c}, \mathrm{b}, \mathrm{a}$ menunjukkan bahwa terdapat perbedaan nyata akumulasi kadar logam berat di setiap perlakuan

\section{Simpulan}

\section{SIMPULAN DAN SARAN}

Pemberian pestisida, pupuk organik dan kombinasinya meningkatkan akumulasi logam berat $\mathrm{Cr}$ pada tanah budidaya dan tanaman kentang (Solanum tuberosum L.).Peningkatan kandungan logam terjadi sejak bulan-1 di setiap perlakuan yang menunjukkan trend yang mirip, yaitu semakin bertambah disemua bagian tanaman.

\section{Saran}

1. Memilih pupuk / pestisida yang memiliki kadar logam berat lebih rendah. Serta mengurangi frekuensi penggunaan pupuk kimia dan pestisida.

2. Mengolah lahan pertanian dengan menambahkan bahan yang dapat menekan kadar logam berat dalam tanah seperti penggunaan arang atau serbuk gergaji.

3. Menggunakan bibit kentang yang tidak tercemar logam berat $\mathrm{Cr}$.

\section{UCAPAN TERIMAKASIH}

Penulis mengucapkan terimakasih kepada I Made Saka Dharmayasa, Dewi Wahyuni, dan Ni Wayan Trisna Dewi yang telah membantu dalam mengumpulkan data dan analisis di Laboratorium Bersama FMIPA Universitas Udayana. 


\section{DAFTAR PUSTAKA}

[Deptan] Departemen Pertanian. 2006. Peraturan Menteri Pertanian Nomor 02/Pert/HK.060/2/2006 tentang Pupuk Organik dan Pembenahan Tanah. Jakarta: Deptan.

Edwards, C.A., 2017. Factors that Affect the Persistence of Pesticides in Plants and Soils, Rothamsted Experimental Station,Harpenden,Herts., UK.55: 39-55.

Hidayat, B. 2015. Remidiasi tanah tercemar logam berat, dengan menggunakan Biocha, Jurnal PertanianTrofik 2(1): 31-41.

Kartika, V., Tandjung, S.D \& Sunarto. 2002. Akumulasi Logam Berat $\mathrm{Cr}$ dan $\mathrm{Pb}$ pada Tumbuhan Mangrove Avicennia Marina Di Muara Sungai Babon Perbatasan Kota Semarang Dan Kabupaten Demak Jawa Tengah. UGM Yogyakarta. 9 (3): 137-147.

Khatimah, H. 2006. Perubahan Konsentrasi Timbal dan Kadmium Akibat Perlakuan Pupuk Organik dalam Sistem Budi Daya Sayuran Organik. Institut Pertanian Bogor. Bogor.
Kusdianti, R. S., Hafsah, \& Eva, T. 2014. Analisis Pertumbuhan Tanaman Kentang (Solanum tuberosum L) pada Tanah yang Terakumulasi Logam Berat Cadmium $(C d)$. UPI. Garut.

Kuwata R. 2010. Experiment 3: Determination of Lead in Soil by Atomic Absorption Spectroscopy. Spring.

Pramono, A \& Wahyuni, S. 2008. Kandungan logam berat pada sistem integrasi tanaman ternak di DAS Serang. Prosiding Seminar Nasional Teknik Pertanian. Universitas Gadjah Mada. Yogyakarta.

Standar Nasional Indonesia (SNI). 2009. Batas Maksimum Cemaran logam Berat dalam IPangan. Badan Standar Nasional.

Yohanes, S., Susrusa, K.B., Permana, M.P \& Triani, A.L., 2017. Optimasi Sistem LEISA dan Pengembangan Model Bioremidiasi Secara In-Situ Pada Budidaya Kentang (Solanum Tuberosum L.) Varietas Granola 
Tabel 4 Data kandungan rerata Logam $\operatorname{Krom}(\mathrm{Cr})$ pada tanah dan tanaman tiap waktu, tiap perlakuan $\mathrm{P}_{1}, \mathrm{P}_{2}, \mathrm{P}_{3}$, dan $\mathrm{P}_{4}$ (satuan $\mathrm{mg} / \mathrm{Kg}$ )

\begin{tabular}{lllll}
\hline Sampel & Bulan ke-O & Bulan ke-1 & Bulan ke-2 & Bulan ke-3 \\
\hline Tanah $\left(\mathrm{P}_{1}\right)$ & 3,485 & 1,938 & 0,889 & 0,786 \\
Tanah $\left(\mathrm{P}_{2}\right)$ & 3,485 & 7,285 & 8,215 & 19,150 \\
Tanah $\left(\mathrm{P}_{3}\right)$ & 3,485 & 4,853 & 6,438 & 16,263 \\
Tanah $\left(\mathrm{P}_{4}\right)$ & 3,485 & 8,245 & 11,978 & 18,425 \\
& & & & \\
Akar $\left(\mathrm{P}_{1}\right)$ & 0 & 1,578 & 8,560 & 9,953 \\
Akar $\left(\mathrm{P}_{2}\right)$ & 0 & 9,680 & 11,449 & 16,063 \\
Akar $\left(\mathrm{P}_{3}\right)$ & 0 & 5,474 & 10,287 & 14,892 \\
Akar $\left(\mathrm{P}_{4}\right)$ & 0 & 12,487 & 15,458 & 20,672 \\
& & & & \\
Batang $\left(\mathrm{P}_{1}\right)$ & 0 & 3,819 & 13,327 & 19,951 \\
Batang $\left(\mathrm{P}_{2}\right)$ & 0 & 10,887 & 14,963 & 32,127 \\
Batang $\left(\mathrm{P}_{3}\right)$ & 0 & 7,462 & 14,152 & 27,659 \\
Batang $\left(\mathrm{P}_{4}\right)$ & 0 & 14,435 & 15,469 & 36,117 \\
& & & & \\
Daun $\left(\mathrm{P}_{1}\right)$ & 0 & 4,890 & 15,365 & 17,235 \\
Daun $\left(\mathrm{P}_{2}\right)$ & 0 & 11,623 & 17,633 & 40,664 \\
Daun $\left(\mathrm{P}_{3}\right)$ & 0 & 8,543 & 14,887 & 23,432 \\
Daun $\left(\mathrm{P}_{4}\right)$ & 0 & 14,334 & 24,263 & 42,765 \\
& & & & \\
Umbi $\left(\mathrm{P}_{1}\right)$ & 1,252 & 2,528 & 7,545 & 12,423 \\
Umbi $\left(\mathrm{P}_{2}\right)$ & 1,252 & 9,545 & 12,344 & 18,628 \\
Umbi $\left(\mathrm{P}_{3}\right)$ & 1,252 & 6,752 & 11,638 & 14,545 \\
Umbi $\left(\mathrm{P}_{4}\right)$ & 1,252 & 14,249 & 15,162 & 26,632 \\
& & & &
\end{tabular}

Bulan ke-3 = pasca panen. $\mathrm{P}=$ perlakuan $; \mathrm{P}_{1}=$ tanpa perlakuan $($ tanaman kentang tidak diberi apa-apa. $\mathrm{P}_{2}=$ tanaman disemprot pestisida; $\mathrm{P}_{3}=$ tanaman diberi pupuk organik saja; $\mathrm{P}_{4}=$ tanaman diberi pestisida dan pupuk organik.

Kurva Kalibrasi

\begin{tabular}{|l|l|}
\hline Konsentrasi/ppm & Absorbansi \\
\hline 0 & 0 \\
3 & 0,0369 \\
6 & 0,0717 \\
12 & 0,1413 \\
16 & 0,1877 \\
\hline
\end{tabular}

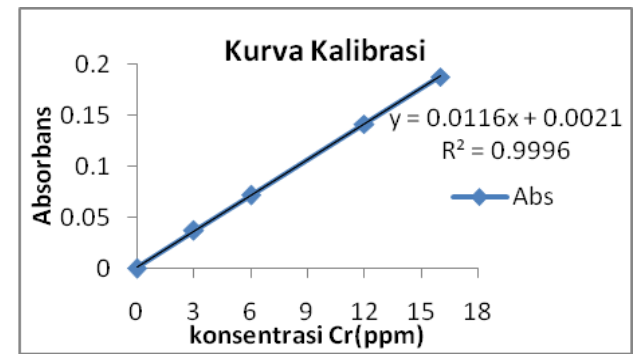

